\title{
Introduction: Researching Democracy and Social Change with Violence in the Foreground
}

\author{
Jenny Pearce
}

\begin{abstract}
There are many studies of violence within specific fields of the social sciences, but the next stage in our evolving understanding of violence may lie with interdisciplinary approaches. By traversing traditional academic categories, violence as a variable may become more visible in its multiple modes. It is through our ability to see the linkages between interpersonal, cultural, collective, political, state, interstate and structural violences that we can gain a better understanding of its persistence in human interactions. Researchers for this IDS Bulletin set out not only to understand contemporary dynamics of violence, but also to work with people trapped in violent places, spaces and histories who were willing to talk about and act upon their situation. Researching violence in an interactive way with those living in the thick of it posed many ethical, safety, epistemological and methodological challenges. These are documented in this IDS Bulletin alongside findings on the dimensions and impact of violence in different contexts.
\end{abstract}

There are many studies of violence within specific fields of the social sciences. Psychology has given insights into individuals, aggressive instincts and violent behaviour; epidemiology has highlighted violence as a public health issue; anthropology has focused on the cultural interpretations and meanings of violence; sociology has researched and theorised collective and group violence and violence within families. Historical sociology has provided a longitudinal analysis of political violence and revolutions and the violence associated with state-building, while political science and international relations have studied state violence, intra- and interstate wars. There have also been valuable efforts to conceptualise violence by political philosophers and peace thinkers (Arendt 1969; Galtung 1969; Bourdieu 2004). A next stage in our evolving understanding of violence may lie more with interdisciplinary fields, such as peace, development and gender studies.

By traversing traditional academic categories, violence as a variable may become more visible in its multiple modes. It is through our ability to see the linkages between interpersonal, cultural, collective, political, state, interstate and structural violences that we can trace the intergenerational transmission of violence through time and space and gain a better understanding of its persistence in human interactions (Pearce 2006, 2007). Such interdisciplinary fields tend to have a normative as well as scholarly interest in the emergence of democratic forms of politics and progressive social change. At the same time as collecting data on how violence affects human interaction across the many spaces of socialisation - from family to community to the construction of the nation state itself - we can ask other questions. How does violence impede this normative project? How does social action emerge in violent contexts? How can it deepen democracy, promote social change and reduce violence?

The Violence, Participation and Citizenship (VPC) group of the IDS's Development Research Centre on Citizenship, Participation and Accountability ${ }^{1}$ sought to answer these questions through research projects in four countries where chronic violence blights regions, subregions and cities. In this IDS Bulletin, we bring 
together reflections on the conduct of this research, together with supplementary commissioned articles covering other examples from violence-torn countries in the global South.

A DVD is included with this IDS Bulletin which gives examples from the participatory videos that were made by in Brazil, Mexico and Nigeria by members of the VPC group. It also includes reflection on the use and challenges of using this methodology and offers further insights into the research of the VPG group to accompany this IDS Bulletin.

\section{The Violence, Participation and Citizenship Research Group}

The research group began with four overarching research questions:

- How do/can people begin processes of participatory social action in contexts of violence?

- What kind of social action reduces and/or prevents violence?

- What kind of social action contributes to citizenship in violent contexts?

- How can our research group contribute to peaceful social transformation?

The link between social action and violence gave the research process a normative component, which greatly shaped the methodology.

Researchers set out not only to understand contemporary dynamics of violence, but also to work with people trapped in violent places, spaces and histories who were willing to talk about and act upon their situation. In Jamaica, they worked with children in the so-called 'garrison' neighbourhoods of Kingston, as well as in middle class suburbs of the city, where lives were more indirectly affected by the high levels of urban violence. In Brazil, they worked with community researchers living in the midst of drug gang and militia counter gang violence in the favelas (slums) of Rio de Janeiro, and in a better off housing estate bordering a violencetorn favela. In Nigeria, they worked with communities in the northern states of Kaduna, Kano and Plateau, increasingly segregated following violent outbreaks in the name of religious differences. Finally, in the poor and indigenous southern states of Guerrero and Chiapas in Mexico, they worked with local NGOs committed to making visible the violence experienced within indigenous communities, and the failure of the education, health and justice systems to recognise its impact.

In each case, the researchers sought to document the dimensions as well as the impact of violence. They used a range of methodologies for this, including a questionnaire survey, as well as more qualitative methods such as semi-structured interviews and innovative participatory methods. The survey helped formulate guiding questions for the participatory action part of the research. For instance, it informed the drama which the Nigerian researchers developed with their community interlocutors. In Brazil, the survey was carried out by community researchers and influenced the participatory videos they subsequently produced. In Mexico, the survey was organised in a participative way through the NGOs and their grassroots collaborators and on at least one occasion brought them face to face with threats. In Jamaica, children themselves were enlisted to do the survey, once trust had been built.

\section{Structure}

Researching violence in an interactive way with those living in the thick of it posed many ethical, safety, epistemological and methodological challenges. This IDS Bulletin captures aspects of these. Section One discusses some of the innovative ways in which the group combined research and action-oriented methods. Perversely, violence inhibits participation in community social and political life, but fosters it also, as people adapt to the threats they live with and seek ways to diminish them (Pearce 2007). Researchers used methods to enhance participation and social action which could potentially be sustained beyond the research process itself, notably drama, video, a Universityaccredited diploma, and transformative education workshops.

Section Two looks at the challenges of collecting data in violent contexts. The first article explains and analyses the group's efforts to combine quantitative and qualitative methods. This is followed by the first of our invited articles, from South Africa, which discusses a social survey in a Cape Town township. Although in this case the survey itself was not focused on violence, the article explores how surveys in violence-prone areas adapt to the risks involved, 
and how this can bring violence from background to foreground as a factor in the everyday lives of surveyed residents.

Violence has differential impacts, and the research group worked with a range of social actors and social classes. Section Three focuses on youth. As well as the Jamaican research with children, two more invited articles focus on research with ex-combatant children and violent youth in Colombia. In Section Four, we unpack further the gender dimensions of researching violence, with contributions from El Salvador and Sri Lanka, two countries with long experience of civil war and, notably in the Salvadorean case, high levels of postwar social violence.

The final section, Section Five, consists of short reflective Notes on a range of difficult questions that arise in the field when researching violence, focusing on experiences from Jamaica and Brazil. They problematise risk, access and efforts to use research to influence policymakers. The conclusion summarises what we have learnt from the articles in terms of violence, social action and research.

In this introduction, I focus on why it is important to bring violence into the foreground when researching democracy and social change in the global South. I begin with a discussion of the dimensions of the problem in the countries represented in this IDS Bulletin, and move to what the contributions tell us about living in the midst of violence and the challenges this poses for building democratic citizenship.

\section{Living with violence: dimensions and definitions of the problem}

The late twentieth and early twenty-first centuries have highlighted the multifaceted nature of violence in an unprecedented way. Often treated as an unfortunate backcloth to continuous human progress, the constant expansion of violence in human society suggests that it is in fact a major and persistent variable and not just a dependant one. By bringing it to the foreground, the exclusionary logic of violence can be made visible, as can social action to overcome this logic and potentially challenge the assumption that violence is an inevitable feature of human behaviour and interaction.

In his history of the twentieth century, Hobsbawm (1994) compared violence negatively with the material, intellectual and moral [Hobsbawm's italics] progress of the nineteenth century, concluding that,

it was without doubt the most murderous century of which we have record, both by the scale, frequency and length of the warfare which filled it, barely ceasing for a moment in the $1920 \mathrm{~s}$, but also by the unparalleled scale of the human catastrophes it produced, from the greatest famines in history to systematic genocide.

(Hobsbawm 1994: 13)²

The twenty-first century opened in continuity rather than rupture with this past, suggesting that it might even surpass its predecessor in numbers of victims. In the last decade of the twentieth century, there appeared to be a disturbing expansion of new phenomena related to violence. These include 'new wars', distinguished from large scale, interstate conventional wars of the past by their intrastate character, massive human rights violations and connections to organised crime (Kaldor 1999); disorganised and privatised violence (Duffield 2000); postwar social violence (Geneva Declaration 2008); and drug-related urban violence. Some phenomena, such as rape as a weapon of war, by no means new, came to be recognised as never before, as did the high prevalence of violence in the intimate spaces of the home, unrelated to war.

Global violence at the beginning of the twentyfirst century had become, according to the World Health Organization, a public health issue. In 2002, it published the first Global Report on Violence and Health (WHO 2002a). It calculated that in the year 2000, 1.6 million people lost their lives through violence, 28.8 per 100,000. Around half of these were suicides, one-third homicides and one-fifth the result of armed conflict. Every day 4,000 people die because of violence (WHO 2004), roughly the same number who die from tuberculosis, and more than the daily toll of 3,500 people who die from malaria. Over 90 per cent are in low and middle income countries (WHO 2004). Violence is among the leading causes of death of young people between the ages of 15 and 44 , accounting for 14 per cent of male and 7 per cent of female deaths in this age group (WHO $2002 \mathrm{~b}$ ). Three quarters of the victims of homicide are young men, notably in the 15-29 age group. 
Table 1 Intentional homicide rates for researched countries

\begin{tabular}{|c|c|c|}
\hline \multirow[t]{2}{*}{ Country } & \multicolumn{2}{|c|}{ Intentional homicide rate $/ 100,000$} \\
\hline & Low estimate & High estimate \\
\hline South Africa & 39.5 & 69.0 \\
\hline Colombia & 45.5 & 61.1 \\
\hline El Salvador & 56.4 & 57,5 \\
\hline Jamaica & 33.7 & 55.2 \\
\hline Brazil & 26.2 & 30.8 \\
\hline Nigeria & 1.8 & 17.7 \\
\hline Mexico & 10.9 & 11.3 \\
\hline Sri Lanka & 6.9 & 7.2 \\
\hline
\end{tabular}

Source United Nations Office on Drugs and Crime (UNODC) 2008

Men are victims of nearly 80 per cent of all homicides, 60 per cent of suicides and 80 per cent of violence-related injuries severe enough to need medical attention (WHO 2004).

Figures for violent death are most severe in lowto middle-income countries: 32.1 per 100,000, twice as many as in high-income countries (WHO 2002b). A study correlating violent deaths with the UNDP's Human Development Index (HDI), found that the homicide rate in countries with low human development is more than three times higher than the average rate in countries with high or medium human development. At the level of individual countries, the HDI itself includes the impact of already high levels of violence on a range of indicators (Geneva Declaration 2008). These statistics do not convey the full picture of injury and trauma not resulting in homicide. In some locations, high levels of everyday violence have become the norm. The VPC research found that most respondents in the four countries liked living in their communities, despite the high levels of violence, which most residents did not imagine could be addressed and had come to accept as a 'normal' part of their lives (Justino et al., this IDS Bulletin).

The WHO (2004) has also explored the multifaceted character of violence. It discusses forms of interpersonal violence, such as youth violence, child abuse, intimate partner violence, sexual violence, abuse of the elderly; as well as self directed violence; and collective violence, which includes social, political, state and economic violence. This spectrum of violences induces researchers to ask whether all are interlinked in some complex way. Evidence does point to one kind of violence leading to others: from perpetrators of violence who have previously been victims of violence in childhood, to the experience of collective political violence increasing the likelihood of violence in intimate spaces. Such intergenerational cycles over time are also reproduced across spaces, from the private and domestic to the street, the wider community and institutions such as schools and prisons and even the workplace.

Willingness to use violence, particularly amongst adolescent male youth, is harnessed for political purposes by leaders, thereby embedding violence in processes of state construction. We might describe the accumulated impact of these intergenerational and interspatial violences as 'chronic violence' (Pearce 2007). A useful definition of such a condition is homicide rates that surpass the average identified ${ }^{3}$ for five years or more, together with high levels of injury and harm not necessarily resulting in death in several socialisation spaces at once.

Impunity fosters more violence. Inadequate and corrupt security and legal systems in many contexts mean that acts of violence go unpunished. Jamaica's 'organised' political violence of the 1960s evolved over two decades into drug-related violence controlled by independent 'dons', wielding violence over entire neighbourhoods. Children in such areas were born to the sound of gunshots. In Colombia, political and social violence constantly fuel each other, their boundaries blurred. Erstwhile political organisers for guerilla or paramilitary groups end up as enforcers for protection rackets. 'Violence gives birth to itself', write Scheper-Hughes and Bourgois (2004: 1), 'so we can rightly speak of chains, spirals, and mirrors of violence - or, as we prefer - a continuum of violence'.

The most recent homicide rates for the eight countries covered in this IDS Bulletin are listed in Table 1. By way of comparison, the figure for intentional homicides from the same source in England and Wales is 1.6 per 100,000 , and for the USA there is a low of 5.4 and a high of 5.9. These statistics were compiled from a number of 
datasets, so where sufficient data are available, a 'low' and a 'high' estimate is given.

UNODG emphasise the need for caution in interpreting the statistics, due for instance to different legal definitions of homicide, but also to other conceptual challenges. For UNODC, intentional homicide includes domestic disputes that end in a killing, interpersonal violence, violent conflicts over land resources, violence between gangs over turf or control, and predatory violence and killing by armed groups. However, it does not capture deaths from armed conflict, where killings are committed by more or less cohesive groups of up to several hundred rather than by individuals or small groups (UNODG 2008). There are many other problems with current compilations of homicide statistics, reflecting issues like inadequate national level reporting, and the inclusion of attempted murder in murder statistics (Chon 2007).

Homicides per 100,000 people are the most common measure of levels of violence. The UNODG defines homicide as 'unlawful death purposefully inflicted on a person by another person' (UNODC 2008: 1). The statistics do not tell us about violence which does not result in death, nor about the spatial, temporal or social intensities of violence. South Africa's homicide rate is very high at 39.5 or 69.0 per 100,000 , but for the township of Khayelitsha in Cape Town it is even higher, at 106 per 100,000 (Nleya and Thompson, this IDS Bulletin). In Colombia, where homicide rates are notoriously inaccurate, the figure reached 381 in Medellin in 1991, and then dramatically declined to 28.6 by 2007 (Baird, this IDS Bulletin). However, even this city-level statistic fluctuates considerably in a short time, so great caution is needed in interpreting annual figures as well as differentiating by location. In Nigeria, communal violence in the name of religion erupts in intense waves. This cost an estimated 1,000 lives in Jos, Plateau state in 2001, and a further 1,000-2,000 over the next three years (Human Rights Watch 2005); newspapers reported a further 300-400 deaths in another wave in December 2008.

While the homicide statistics above do not suggest that violence is as widespread in Nigeria as in Central and South America, cycles of violence in the name of religion have extended across north and central Nigeria, and communities have become increasingly segregated and vulnerable to a phenomenon with deep social and historical roots (Abah and Okwori; Harris, this IDS Bulletin). In Sri Lanka, the homicide figures do not convey the level of deaths related to the armed conflict, which after a 2002 peace agreement resumed in 2006 at a cost of over 4,000 lives in that one year.

While Sri Lanka, Colombia and El Salvador are all countries which have experienced internal wars of one kind or another, and South Africa experienced the prolonged struggle against apartheid, high levels of violence in Brazil and Jamaica reflect the accumulated impact of drug trafficking, criminal activity and impunity in Latin America and the Caribbean.

Violence throws up difficult issues of measurement, but also of definition (Pearce 2007). Restricted definitions focus on direct physical violence; progressively wider definitions embrace symbolic (Bourdieu 2004) and structural (Galtung 1969) violence. The VPC group studies tended to emphasise different aspects of these definitions. In Mexico, for example, systematic discrimination against indigenous communities had symbolic and structural violence effects. At a workshop I attended with the Mexican research team and grassroots participants in Chiapas in December 2008, the encouragement to speak on a topic long clouded in shame and concealment had a powerful effect. Indigenous women wept as they recounted their experiences of subjugation as well as direct physical violence in the home from husbands and fathers in particular. Even where violence was not direct, many had internalised a sense of worthlessness which had physical effects on them. This illustrates symbolic violence, where people submit, often despite themselves, to the dominant judgements of others, 'experiencing the insidious complicity that a body slipping from the control of consciousness and will maintains with the censures inherent in the social structure' (Bourdieu 2004: 341). Equally traumatic for participants were their tales of interacting with a health system which systematically neglected and even ignored the needs of indigenous rural communities living far from medical provision of any kind. Here, the meaning of structural violence is conveyed in story after story of walking miles to health centres, only to be told to come back another day 
or to be kept waiting while feeling very sick. At least two stories were told of babies who died in childbirth for lack of obstetric care. These are examples of preventable deaths, a form of violence embedded in unequal social structures.

In its 2002 report, the WHO came up with a definition that aimed to embrace this wide range of meanings, and cases where violence does not necessarily lead to injury or death. It defines violence as:

The intentional use of physical force or power, threatened or actual, against oneself, another person, or against a group or community, that either results in or has a high likelihood of resulting in injury, death, psychological harm, maldevelopment or deprivation.

(WHO 2002a: 5)

That is, violent acts can be physical, sexual, psychological as well as the result of deprivation or neglect. There is much merit in this definition, although it is important to retain distinctions and not to reduce violence to 'one problem' to be 'solved as a whole with one set of techniques' (Coady 1999: 31).

Most contributors to this IDS Bulletin focus on the consequences of living in the midst of direct physical violence, often chronic; but other kinds of violence are clearly present. Among the insights they have generated is how violence researchers must attune themselves differently to such contexts and become attentive listeners to their particular silences and sounds as well as watchful to the visual as well as verbal expressions of living with violence. They must carefully trespass the visible and invisible boundaries of violence and learn to navigate the possibilities for research and action which different kinds of violence allow and disallow. By getting to know features of violent and chronic violent contexts, researchers can sensitise themselves better to the many challenges of researching such contexts.

\section{The sights, sounds and silences of violence: learning to look and listen}

Violence-torn contexts are very particular research environments. Several of the contributions to this IDS Bulletin attest to how the violence researcher needs to develop new sensitivities in these environments. Wheeler discusses the constant cycle of 'editing out' in the favelas where she worked, as residents learnt to censor themselves, never certain whether something they said would be misinterpreted or reported back to the drug traffickers. She had to learn to listen to often contradictory opinions; violence in the favelas had 'no face or name'. Moncrieffe uncovers the differences in what could be voiced by children in the most violenceprone garrisons, and those in the more upper class neighbourhoods. Researchers were unprepared for the 'raw candour' of the poor children exposed to daily violence who spoke openly of the loss of parents and siblings, compared with the controlled environments and silences they had to accept in the wealthier localities. For Hume, the silences of violence are deeply gendered in a complex way. It is not just a silence around the practice of violence against women - as she points out, a 'public secret' - or not being allowed to speak - it is the expectation that women should not 'make a fuss'. Even as more women do gradually find voice on the subject, men also find voice in new narratives to explain away their behaviour, constructing new silences in the process.

Talk about violence is muted in other ways, and they vary with context. Internalised fear and painful memories permeate all the articles in this IDS Bulletin, posing particular challenges when working with perpetrators of violence.

Friendliness, humour and 'good listening' proved invaluable to Baird in Medellín, Colombia, as he sought to understand but not condone individuals responsible for serial killings. In Sri Lanka, de Silva worked with life stories of former combatants, and concluded that memory is partially conditioned by the listener. The researcher as listener influenced the narrative not just by the questions asked but through face, mien and gender. In this case, the researcher was able to positively listen to silences, aware that she was facilitating a process of subject construction. In Colombia, Jiménez demonstrates how complex silences can be, as he and his colleagues attuned to the way former child combatants responded to the word 'death'. He notes that 'what was most heard was the silence that invariably followed mention of the word death [...] It was a terrifying silence'. In this case, the researchers demonstrated the value of intuitive listening, which enabled them to interpret this silence and identify dignity, memory and mourning as the 
keys to releasing the young people from their emotional debt to the armed groups on whose behalf they had killed.

Some of the methodologies the VPC group used to research violence aimed to make it visible, as well as to express visually what words could not convey. This was the role of drama and participatory video in all our cases.

\section{The visible and invisible boundaries of violence: learning to trespass}

Violence-prone areas have all kinds of boundaries, and researchers face a daunting task in learning to recognise them and then find safe ways of crossing them. In Jamaica, the children urged researchers to focus on the physical, social and psychological boundaries which they found the hardest to confront in their violent environments. This resulted in a search for 'safe spaces' where the children might talk more freely about their experiences, which for the poorest children was the school. Eventually, a radio programme also became a 'safe space', where children from across the social divides could talk anonymously outside the limiting boundaries of their normal lives.

In Rio, the researcher had to literally cross a boundary every day as she left her middle class neighbourhood for the favela and the housing estate. Here, the boundaries were audible and visible in the sound of gunshots and the sight of police cars. However, other boundaries she navigated were less visible and could be accidentally transgressed, such as getting on the wrong side of an armed faction newly in charge, or being caught in crossfire. Sometimes, too, she had to choose to trespass across a known boundary in order to protect the research. Such a moment was when she refused to change her community research team as demanded by the head of the militia in control of the favela. Her calculation was based on carefully accumulated knowledge of what the militia found threatening.

Baird, in Medellín, Colombia, had to consider carefully whether and how to trespass boundaries imposed by armed actors whose delineations were never made clear. By first 'hanging out' with an NGO with long experience in areas controlled by right wing paramilitary, he was able to reduce risks by becoming more 'streetwise' and make the dangers 'less unpredictable' before approaching armed actors themselves. Another boundary issue was the appropriate degree of rapport to construct with subjects known to have committed terrible acts; here was one of many ethical boundaries for violence researchers to confront. In Nigeria, Harris had daunting religious, cultural and gender boundaries to cross when attempting to persuade Muslim men, who had once been at the heart of a spate of violence over the prospective introduction of Sharia into criminal law, to participate in education for transformation workshops. Here, prior experience in Muslim Tajikistan and knowledge of Islam enabled the researcher to gain acceptance and respect and even to work with both sexes.

\section{Organised and disorganised violence: learning to navigate}

This IDS Bulletin encompasses a range of types of violence, and teaches us that the researcher faces different challenges in exploring each of them. In Jamaica and Brazil, researchers worked in 'parallel communities', where the national State had little or no authority. In these communities, violence is exercised by armed actors, usually involved with criminal activities. The violence tends to be organised and have rules, as Wheeler acknowledges. What made her task difficult was that her research questioned the legitimacy of violent social actors in the community - to whom legitimacy was so desirable. In Jamaica also, violent actors are also community protectors, and there is a structured hierarchy of authority, although violent competition for power and control also exists. No researcher can ignore the prevailing authority structures when entering and conducting research. This works to the researcher's benefit in a sense, as once permission is granted, a certain protection ensues. However, as Wheeler points out, the research then has to be careful not to be or appear to be in cahoots with the controlling faction or leader, as this would limit trust-building with those in the community seeking a pathway out of violence, as well as endangering the research vis-à-vis rival factions.

In other violent contexts in this IDS Bulletin, the violence is much less organised. In Medellín, Baird talks of learning to understand the 'rules' of local violence. These rules have unravelled considerably as paramilitaries entered a demobilisation process and are no longer 
formally 'organised'. Everyone knows that structures of some kind remain, but penetrating them is more challenging and arguably more dangerous than when the structures were more overt. In central and northern Nigeria, violence has had the effect of creating new boundaries between the Christian and Muslim communities. Here violence is less everyday, but erupts in what appears to be an organised fashion in response to certain triggers. As long as they were rooted in the community through local community-based organisations, the researchers could facilitate the public dramatisation of the violence, with community participation.

Whatever the levels of organisation and disorganisation, violence damages and 'degrades' (Wheeler, this IDS Bulletin) the social fabric of communities, so that social interactions are distorted. Researchers enter a world where they are forced to engage with violent actors as well as victims, and seek to build trust for research and remedial action where trust in life itself has been deeply eroded. The violence researcher must learn to read constantly between and beyond the lines.

\section{Conclusion: building citizenship, tackling violence}

It is not possible to understand democracy and social change in the countries covered by this IDS Bulletin without taking on board the violence dynamics which have taken hold in so many social spaces and are transmitted through time as well as space. Intergenerational cycles of violence become harder to interrupt the longer they are left unchecked. In many of our cases, violence is correlated with poverty and exclusion. However, better off areas are also affected by it, as our studies illustrate. Wealthier citizens retreat behind gates, generate their own taboos around certain topics of discussion, and hire private security, leaving the marginalised areas to poorly financed, trained and often abusive and corrupt public security (Abello and Pearce 2009).

In this way, citizenship becomes a spatially limited concept. Formal rights and freedoms cannot be exercised in a meaningful way for those born into these violence-prone territories who are unable to escape them except by shutting themselves into their homes and compounds. People are partially silenced, forced to respect boundaries imposed by threat, and live in contexts where the trust necessary for positive social interaction has collapsed. Men and women are affected, but differentially, with violence against women an ongoing means to perpetuate gender inequality as well as a reflection of it. The goal of changing masculinities is stymied by the fact that male identities are so shaped by acts of violence, both as perpetrators and victims. Although campaigns on violence against women and children have increased awareness of the social impact of violence, there is far less recognition of its impacts on democracy and development and the way it limits citizenship.

However, positive social action does take place in violent contexts. Our research sought both to recognise such action and to foster it. This took various forms, such as making violence visible as with the Diploma on Social Action against Violence in Mexico ('The Violence Diploma'), or the participatory theatre in Nigeria - or voicing violence through the 'extended language' (Wheeler, this IDS Bulletin) of participatory video. It might be about reconstructing subjectivities as with ex-combatants in Colombia and Sri Lanka, which gives dignity and release from violent pasts. It might be through working with children in a bid to interrupt the intergenerational cycles, as in Jamaica.

We also tried to find ways of bringing policymakers into the discussion on violence. Trust in government and public institutions offering protection and security in our research contexts has either broken down, or never been established. It is difficult to conceive of meaningful citizenship without such trust. Encouraging policymakers to recognise social action against violence and support it was one of our objectives. This met with some success in Rio where the local government promoted the making of participatory videos in other favelas after watching the one made by the community researchers.

It is difficult and arguably unethical for violence researchers to ignore the normative potentialities of their research. Our research group decided to integrate them consciously into our research objectives at the same time as building knowledge. Preventing and addressing violence means reversing the trend towards 
violence being normalised. One pathway for this challenge is through social action which ultimately might mutate into personal and collective transformation, political action and campaigns. By ensuring that violence becomes

\section{Notes}

1 See www.drc-citizenship.org/ for further information. The VPC research group was jointly convened by Oga Steve Abah and Jenny Pearce.

2 One estimate suggests that around 191 million people died in the 25 major instances of collective violence in the twentieth century; 60 per cent of them non-combatants (WHO 2002a).

\section{References}

Abello, A. and Pearce, J. (2009) "'Security from Below": Humanising Security in Contexts of Chronic Violence', IDS Bulletin 40.2: 11-19

Arendt, H. (1969) On Violence, San Diego: Harvest Books

Bourdieu, P. (2004) 'Gender and Symbolic Violence', in N. Scheper-Hughes and P. Bourgois (eds), Violence in War and Peace: An Anthology, Oxford: Blackwell

Chon, D. (2007) 'Problems with the Data on International Homicide Rates', paper presented at the annual meeting of the American Society of Criminology, Atlanta, Georgia, www.allacademic.com/meta/ p201038_index.html (accessed 11 December 2008)

Coady, C.A.J. (1999) 'The Idea of Violence', in M. Steger and N. Lind (eds), An Interdisciplinary Reader: Violence and its Alternatives, Basingstoke: Macmillan

Duffield, M. (2000) 'Globalization, Transborder Trade, and War Economies', in M. Berdal and D. Malone (eds), Greed and Grievance, Economic Agendas in Civil Wars, Boulder, Colorado: Lynne Rienner

Galtung, J. (1969) 'Violence, Peace and Peace Research', Journal of Peace Research 6.3: 168-82

Geneva Declaration (2008) Global Burden of Armed Violence, www.genevadeclaration.org/pdfs/ Global-Burden-of-Armed-Violence.pdf (accessed 4 January 2009)

Hobsbawm, E. (1994) Age of Extremes: The Short Twentieth Century, London: Michael Joseph less and less acceptable and less justified in whatever form it takes, new and more inclusive spaces for participation are opened; citizenship is built and strengthened, social change fostered and democracy deepened.

3 The WHO's 2002 average of 32.1 per 100,000 for low to middle income countries is based on a reasonably comprehensive survey, but limited by inadequate country level data; the more recent UNODG (2008) offers an alternative benchmark, based on figures compiled in 2004.

Human Rights Watch (2005) Revenge in the Name of Religion: The Cycle of Violence in Plateau and Kano States, New York: Human Rights Watch

Kaldor, M. (1999) New and Old Wars: Organized Violence in a Global Era, Cambridge: Polity Press

Pearce, J. (2007) Violence, Power and Participation: Building Citizenship in Contexts of Chronic Violence, IDS Working Paper 274, Brighton: IDS

Pearce, J. (2006) 'Bringing Violence "Back Home": Gender Socialization and the Transmission of Violence through Time and Space', in Helmut Anheier, Mary Kaldor and Marlies Glasius (eds), Global Civil Society 2006/07, London: Sage

Scheper-Hughes, N. and Bourgois, P. (2004) (eds) Violence in War and Peace: An Anthology, Oxford: Blackwell

UNODC (2008) International Homicide Statistics and link to Metadata and Methodological Text, United Nations Office on Drugs and Crime, www.unodc.org/unodc/en/data-and-analysis/ ihs.html (accessed 4 January 2009)

WHO (2004) Violence Prevention Alliance: Building Global Commitment for Violence Prevention, Geneva: World Health Organization

WHO (2002a) World Report on Violence and Health, Geneva: World Health Organization

WHO (2002b) World Report on Violence and Health, Executive Summary, Geneva: World Health Organization 